\title{
LIST OF MAPS, FIGURES, AND TABLE
}

\author{
MAP 1 Distribution of Western Han royal tombs 4 \\ MAP 2 Western Han prefectures and kingdoms, 143 BCE 5 \\ MAP 3 Topographical map of Mancheng tombs nos. 1 and $2 \quad 12$ \\ MAP 4 Northern Zones on China’s frontier 111
}

FIGURE 0.1 Excavation photo of Houjiazhuang tomb no. $1001 \quad 2$

FIGURE 0.2 Distant view of Mancheng tombs nos. 1 and $2 \quad 13$

FIGURE 0.3 Tentative reconstruction of Mancheng tomb no. $1 \quad 14$

FIGURE 1.1 Plan and section of Mancheng tomb no. $1 \quad 28$

FIGURE 1.2 Plan and layout of rear chamber in Mancheng tomb no. 131

FIGURE 1.3 King Liu Sheng's jade suit 32

FIGURE 1.4 King Liu Sheng's jade seals 38

FIGURE 1.5(A) Jade figure from the outer coffin of Mancheng tomb no. 139

FIGURE 1.5(B) Inscription on bottom of jade figure identifying it as "an old jade man" 39

FIGURE 1.6 Inlaid bronze $h u$ vessel with bird script inscription 49

FIGURE 1.7 Plan of rear chamber and grave goods in Mancheng tomb no. 151

FIGURE 1.8 Bronze lamp of the "Bright Hall of the Forest of Pepper Trees" 55

FIGURE 1.9 Bronze story-tellers 57

FIGURE 1.10 Bronze dildo and stone "testicles" 58 
FIGURE 2.1 Plan and section of Mancheng tomb no. 265

FIGURE 2.2 Queen Dou Wan's jade suit 67

FIGURE 2.3 Genitalia in jade suits from Mancheng tombs nos. 1 and 268

FIGURE 2.4 Necklaces from Mancheng tombs nos. 1 and $2 \quad 71$

FIGURE 2.5 Rear chambers of Mancheng tombs nos. 1 and 275

FIGURE 2.6 Plan of Zhao Mo's tomb 76

FIGURE 2.7 Lamp of Palace of Lasting Trust 82

FIGURE 2.8 Wager coins with inscriptions 86

FIGURE 2.9(A) Layout of rear chambers of Mancheng tombs nos. 1 and $2 \quad 89$

FIGURE 2.9(в) Layout of side chambers of Mancheng tombs nos. 1 and 289

FIGURE 2.10 Plan and burial objects in front chamber of Mancheng tomb no. 294

FIGURE 2.11(A) Plan of standard Chinese house 96

FIGURE 2.11(B) Plan of palace in Western Han archaeology 96

FIGURE 2.12 Plan of the residential complex of King Liu Wu 98

FIGURE 2.13 Front chambers of Mancheng tombs nos. 1 and $2 \quad 102$

FIGURE 2.14 Plan of Mt. Baoan tombs nos. 1 and $2 \quad 103$

FIGURE 3.1(A) Beaded necklace from Mancheng tomb no. 1109

FIGURE 3.1(в) Beaded necklace from Mancheng tomb no. 2109

FIGURE 3.1(C) Beaded necklace from Jundushan cemeteries 109

FIGURE 3.2(A) Bronze short sword from Mancheng tomb no. 1113

FIGURE 3.2(B) Bronze short swords from Jundushan cemeteries 113

FIGURE 3.3(A) Iron short sword from Mancheng tomb no. 1114

FIGURE 3.3(B) Iron short sword from Arzhan tomb no. 2114

FIGURE 3.4 Bronze feline from King Cuo's tomb 120

FIGURE 3.5(A) Bronze $h u$ vessel from Mancheng tomb no. 2121

FIGURE 3.5(В) Bronze so-called Ti shi hu vessel 121

FIGURE 3.6(A) Inlaid bronze $h u$ vessels from Mancheng tomb no. 1122

FIgURE 3.6(в) Wool saddle cloth from Pazyrik Kurgan V 122

FIGURE 3.7(A) Gilt bronze elks from Mancheng tomb no. $1 \quad 123$

FIGURE 3.7(B) Bronze animal finials from Ordos 123

FIGURE 3.8(A) Gilt bronze feline-shaped figures from Mancheng tomb no. $1 \quad 125$

FIGURE 3.8(в) Inscriptions on the bottoms of feline-shaped figures 125

FIGURE 3.9(A) Plan of Guyuan tomb IIIM1 with bronze animal figures 127

FIGURE 3.9(в) Bronze animal figure from Guyuan tomb IIIM1 128

FIGURE 3.9(C) Gold deer figures from Filippovka 128

FIGURE 3.10(A) Bronze belt plaque from Mancheng tomb no. 1131 
FIGURE 3.10(в) Openwork plaque from Ivolga 131 FIGURE 3.11(A) Bronze needle case from Mancheng tomb no. $1 \quad 132$ FIGURE 3.11(В) Bronze needle cases from Jundushan cemeteries 132 FIGURE 3.12(A) Glazed pot from Mancheng tomb no. $1 \quad 133$ FIGURE 3.12(в) Ceramic pot from Mancheng tomb no. $1 \quad 133$ FIGURE 3.13(A) Bronze $f u$ cauldron from Mancheng tomb no. 1134 FIGURE 3.13(B) Bronze tripod from Mancheng tomb no. 1134 FIGURE 3.14 "Horse-Face" frontlet from Mancheng tomb no. 1135 FIGURE 3.15(A) Bronze figurines from Mancheng tomb no. 2136 FIGURE 3.15(B) Inlaid bronze die from Mancheng tomb no. 2136 FIGURE 3.16 Wool carpet from Pazyrik Kurgan V with details 137-38 FIGURE 3.17 Major burial types in early China 145 FIGURE 3.18 Plan and section of Majiayuan tomb no. $1 \quad 148$ FIGURE 3.19(A) Tomb no. 6M200 at Shuozhou 149 FIGURE 3.19(B) Sanfengou tomb no. 2 at Yangyuan 149 FIGURE 6.1(A) Miniature bronze vessels from Mancheng tomb no. 2232 FIGURE 6.1(В) Miniature ceramic well model from Luoyang 232 FIGURE 6.2(A) Mural of preparing food at Dahuting tomb no. 1236 FIGURE 6.2(B) Mural of transporting food at Dahuting tomb no. 1236 FIGURE 6.2(C) Mural of banqueting at Dahuting tomb no. 1236

TABLE 5.1 Some posthumous titles in the Rules for Posthumous Titles text 189 
